\title{
Economic growth and company stock pricing in the global stock market
}

\author{
M. M. Loubochkin \\ Saint Petersburg State University of Economics, \\ 21, Sadovaya ul., St. Petersburg, 191023, Russian Federation
}

For citation: Loubochkin M. M. Economic growth and company stock pricing in the global stock market. St Petersburg University. Journal of Economic Studies, 2018, vol. 34, issue 3, pp. 396-414. https:// doi.org/10.21638/spbu05.2018.303

The current paper proposes a fundamental framework for studying stock pricing within the global stock market and beyond. The matters of asset pricing in general, and stock pricing in particular, within the global stock market have not been discussed and researched thoroughly thus far. While certain aspects, such as correlation and interdependence between national stock markets represented by respective indexes, have been discovered and studied, the foundations and other aspects have largely been omitted. Among these subjects are the nature and reasons of stock price movements for long, medium, and short terms, fundamental differences of price movement for different asset types, and pricing differences between global, regional, and local stock markets. These subjects are largely connected to each other, to inherent qualities of various assets, to fundamental economic laws and, to a certain extent, to economic growth. To analyze these successfully, they must be tied together within a single approach that would define and clarify basic principles of stock pricing for the global stock market and that can be extended to other asset types as well. This would lay a framework for further, deeper studies, as well as clarify and even correct existing studies. The present article aims to accomplish that goal and assist the creation of a more comprehensive, unified approach towards stock pricing within the context of economic growth and beyond, which could be used by both researchers and stock market specialists.

Keywords: economic growth, global stock market, stock pricing, enterprise economy, investment, speculation.

\section{Introduction}

Financial markets play an increasingly important role in the global economy. Stock markets as separate entities and in their totality, forming a single entity commonly referred to as the global stock market by experts who deal with it, are an integral part of financial markets. If the financial system is the lifeblood of the world economy for bringing financial flows to where they are needed, the global stock market is probably the heart. Like almost everything else in the modern world, it is in one way or another, directly or indirectly, connected closely with every other part of the world economy, its development tendencies, and phenomena.

Many assets are traded daily within the global stock market, from government bonds to weather derivatives, and while company stocks might not be the most popular or liquid assets, they are its major pillar by tradition and their very essence. As far as investment

(c) Санкт-Петербургский государственный университет, 2018 
goes, stocks are normally considered the most important part of a well-diversified investment portfolio, followed by government and corporate bonds. Company stocks historically offer some of the highest yields among asset types, on par with real estate and probably even beyond (depending on how the yield is calculated) [Graham, Zweig, 2003]. Moreover, they offer investors different rights, including entitlement to different kinds of income, such as dividends or profit from stock appreciation.

However, stock markets and stock pricing in particular have not been researched thoroughly enough (and probably never will be due to their incredibly complex nature). There is common agreement and strong empirical evidence that stock prices in general grow in the long run, but particular details and the exact mechanism are yet to be described. It is known and proven that they fluctuate chaotically (though not randomly) in the medium and short terms, but different specialists and scientists offer various time frames for "long," "medium," and "short," often without substantiating them [Shiller, 1981; Mirkin, 2014; Shavshukov, 2015].

Moreover, the global stock market as an entity has been researched even less. Few definitions have been offered, even though there are instruments for dealing with it, such as global stock indexes and their derivatives. There is even doubt of the existence of such a thing as a "global stock market," which is based on certain definitions and properties a truly global market is supposed to have. Meanwhile, from a practical standpoint, a very special and fundamentally important dimension of the stock market and financial system, that of making investments, also has to be clearly defined, as will be demonstrated in the present article.

Different matters concerning stock pricing for the medium, short, and extra short (milliseconds) terms still await researchers' efforts to define and explore them. the present work, however, deals first and foremost with pricing in the long run (decades), that based on long economic cycles and economic growth.

Here, we define and explore the link between long term pricing of company stock in the global stock market and economic growth. Based on that link, the exact mechanism and major properties of this stock pricing are determined. Specific important definitions concerning the subject specified and beyond it are offered, along with grounds for them. In short, many "why?" questions are answered and certain tendencies widely considered to be true are specified or corrected.

Conclusions provided can be of use for investors and speculators, as well as various stock exchange governing bodies, governmental or non-governmental. They can be used as a fundamental part of investment strategy creation and enhancement, risk assessment, policy measure development and, of course, as a basis for further scientific research.

\section{The study accomplishments and research objectives}

Much has been written on economic growth and stock pricing as separate phenomena. Their connection has been discussed considerably less. Almost nothing has been said on this connection in the context of the global stock market.

The very definition of global stock market has been somewhat unclear. Most sources understand it as an aggregate of national stock markets for practical purposes [Mirkin, 2011; Wessel, 2010]. From our point of view and for the purposes of this work, it would be more accurate to define it as an aggregate of interdependent national stock markets 
interacting with each other, possessing high freedom of capital movement, and assuming the creation and development of international instruments and regulatory harmonization, while retaining a certain degree of insulation and independence.

It is the global stock market where stock pricing in the context of economic growth has special connotations and some very specific properties. It begins with the growth of the global economy, which in some aspects can be very different from the growth of a country's or a region's economy. This difference translates into stock pricing in aspects dependent on economic growth.

Overall, economic growth in and of itself has been researched well enough and successfully defined in different research papers, with various factors and major factor types rather well known today. Stock pricing, being in some sense a more complex, as well as a more practical, day-to-day subject, is somewhat less clear, even though the amount of research on it is substantial.

Unlike economic growth, stock pricing fundamentally has more dimensions in regard to time frames. Economic growth happens in the long run - it takes decades to happen on a sustainable level. In the short and medium run, the economy, measured by economic indicators such as GDP, does not necessarily grow and can behave differently. This means that the factor of economic growth mostly takes on the predominant role in the long run.

Stock pricing, on the other hand, happens in all time frames, from milliseconds up to decades. In these different time frames, stock pricing might or might not have the same properties and be determined by the same factors. Often, this fact is not taken into account in research, with schoolars not defining which time frames they mean when discussing pricing. This approach creates both uncertainty and mistakes when interpreting data and results for other research in the area using existing work.

Further, the geographic aspect mentioned above has largely been missed. While the framework for mechanisms of economic growth by various economic cycles (first and foremost long-term ones) is generallyclear, it remains uncertain where these cycles and economic growth pertain geographically - i.e. whether they are completely true for global, regional, and national economies in the same manner, or less so. The same question can be asked regarding stock pricing: does it have the same mechanisms on the global and local levels, or are do mechanisms differ to some extent?

No essential answers based on fundamental properties of economic growth or stock pricing have been offered to these issues thus far. Moreover, there is no complex concept depicting mechanisms of interaction between economic growth and stock pricing in different time frames and within different geographic contexts.

Presently, there is enough historical data and evidence from scholarly and practical research of the world economy, stock markets, and economic theory to formulate such a concept. This study offers such a concept, encompassing all time frames and geographies, based on fundamentals of economic theory, world economy, and essential properties of stock market assets, primarily company shares. The approach formulated herein will significantly further the research into the stock market in general and global stock market in particular by eliminating many of fundamental uncertainties and conflicts in terminology, as well as offering grounds for clear and unified definitions of stock market related phenomena, such as investing and speculation. 


\section{Earlier research on economic growth and global stock market pricing}

There has not been much research on economic growth and stock market pricing, especially at the global level. Yet these subjects have been studied more or less thoroughly separately, or together in particular aspects. The main studies related to this subject can be divided in three main groups: studies on economic growth and company stocks (as well as other stock market assets), stock pricing, and pricing within the global stock market. Major works on economic growth and company stocks, as related to this article, can be generally described as follows (Table 1).

Table 1. Major studies related to economic growth and stocks

\begin{tabular}{|l|l|l|}
\hline \multicolumn{1}{|c|}{ Researchers } & \multicolumn{1}{|c|}{ Works } & \multicolumn{1}{|c|}{ Major results } \\
\hline Robert Shiller, 1981 & $\begin{array}{l}\text { Do stock prices move too } \\
\text { much to be justified by } \\
\text { subsequent changes in divi- } \\
\text { dends? }\end{array}$ & $\begin{array}{l}\text { Demonstrated that share prices tend to be more vola- } \\
\text { tile than their fundamental underlying factors. Some- } \\
\text { times prices can be higher as compared to values } \\
\text { justified fundamentally, which creates price bubbles. } \\
\text { At other times, prices can go too low, which indicates } \\
\text { that stock market mechanisms are not completely ef- } \\
\text { ficient }\end{array}$ \\
\hline $\begin{array}{l}\text { Benjamin Graham, } \\
\text { Jason Zweig, 2003 }\end{array}$ & $\begin{array}{l}\text { The intelligent investor: the } \\
\text { definitive book on value in- } \\
\text { vesting }\end{array}$ & $\begin{array}{l}\text { Demonstrated that for large time frames, stock mar- } \\
\text { kets and share prices in particular tend to grow, in- } \\
\text { stead of fluctuate, as in smaller time frames. Such } \\
\text { growth generally corresponds to economic growth }\end{array}$ \\
\hline
\end{tabular}

Notes: table compiled from the sources: Shiller R. Do stock prices move too much to be justified by subsequent changes in dividends? // The American economic review. 1981. Vol.71, no. 3. P.421-436; Graham B., Zweig J. The intelligent investor: the definitive book on value investing. New York: Collins business, 2003. $640 \mathrm{p}$.

At a first glance, these two major works contradict each other: while Shiller notes that stock price movements are often more volatile than their underlying factors, Graham and Zweig claim (and show, using historic evidence) that overall, stock prices move in accordance with economic growth, which can ultimately be the major underlying factor affecting earnings, dividends, and subsequently stock prices through economic mechanisms. The keyword to resolving this issue is "time period" or "time frame".

Indeed, historical data suggests that on fundamentally large time frames, like decades, stock prices tend to grow, and their growth rate does in general correspond to underlying economic growth. Shiller, on the other hand, is discussing somewhat different time periods - mostly medium term, such as years or months (on small time frames, stock price movements mostly depend on factors other than economic indicators and results, which will be discussed below). Within these time periods, price volatility tends to become unreasonably large as compared to fundamental factors.

This example signifies the importance of taking time frames into account when discussing stock pricing. However, both works mostly deal with consequences, not causes, and do not exactly explain economic mechanisms that make these consequences true.

Defining these mechanisms will lead to another important keyword - "geographies". The scale of the geographies discussed - local, regional, or global - determines behav- 
iors of economic growth and resulting stock price movements. In the other words, stock prices have in some aspects different qualities within geographies of different scales - a notion that will we expand upon later.

Fundamental research on asset pricing in general relating to the context of this work is somewhat more numerous, as demonstrated in the table below (Table 2).

Table 2. Major studies related to stock market asset pricing in general

\begin{tabular}{|l|l|l|}
\hline \multicolumn{1}{|c|}{ Researchers } & \multicolumn{1}{|c|}{ Works } & \multicolumn{1}{|c|}{ Major results } \\
\hline Eugene Fama, 1965 & $\begin{array}{l}\text { Random walks in stock } \\
\text { market prices }\end{array}$ & $\begin{array}{l}\text { Developed an efficient market theory, according to } \\
\text { which market information is included into stock } \\
\text { asset pricing. }\end{array}$ \\
\hline $\begin{array}{l}\text { Daniel Kahneman, } \\
\text { Amos Tversky, } \\
\text { 1979; 1992 }\end{array}$ & $\begin{array}{l}\text { Prospect theory: An analysis } \\
\text { of decision under risk } \\
\text { Advances in prospect theory: } \\
\text { cumulative representation of } \\
\text { uncertainty }\end{array}$ & $\begin{array}{l}\text { Through uniting economy and psychology, found } \\
\text { and demonstrated that economic subjects tend to act } \\
\text { irrationally when making economic decisions, and } \\
\text { thus markets in general are not completely efficient. } \\
\text { Their concepts pertain to stock markets in particular: } \\
\text { they notably change our view of stock market and as- } \\
\text { set pricing and make clear the overall possibility of } \\
\text { systematic profit generation by speculators through } \\
\text { the use of market inefficiencies. }\end{array}$ \\
\hline $\begin{array}{l}\text { Ravi Bansal, Amir } \\
\text { Yaron, 2004 }\end{array}$ & $\begin{array}{l}\text { Risks for the long run: a } \\
\text { potential resolution of asset } \\
\text { pricing puzzles }\end{array}$ & $\begin{array}{l}\text { Researched stock pricing over the long run within the } \\
\text { context of predictable and uncertain components of } \\
\text { consumption and dividend growth rates. Created a } \\
\text { model justifying various parameters for stock mar- } \\
\text { ket assets and explaining major features of the asset } \\
\text { market data. }\end{array}$ \\
\hline $\begin{array}{l}\text { Yakov Mirkin, } \\
2002 ; 2011 ; 2014\end{array}$ & $\begin{array}{l}\text { Fezhdunarodnaya praktika } \\
\text { prognozirovaniya tsen nans } \\
\text { finansovyh rynkakh (syre, } \\
\text { aktsii, kurs valyut) } \\
\text { bumy, sistemnye riski } \\
\text { Rynok tsennykh bumag }\end{array}$ & $\begin{array}{l}\text { Conducted research on problems and prospects of } \\
\text { financial and stock market development. He thor- } \\
\text { oughly analyzed pricing factors and modern price } \\
\text { movement prediction methods for various market- } \\
\text { able assets. }\end{array}$ \\
\hline
\end{tabular}

Notes: table compiled from the sources: Fama E. Random walks in stock market prices // Financial analysts journal. 1965. Vol.21, no. 5. P.55-59; Kahneman D., Tversky A. Prospect theory: An analysis of decision under risk // Econometrica. 1979. Vol. 47, no. 2. P. 263-292; Kahneman D., Tversky A. Advances in prospect theory: cumulative representation of uncertainty // Journal of Risk and Uncertainty. 1992. No. 5. P. 297-323; Bansal R., Yaron A. Risks for the long run: a potential resolution of asset pricing puzzles // The Journal of Finance. 2004. Vol.59, no. 4. P. 1481-1509; Mirkin Y. M. International practice of financial markets' price forecasting (commodities, stocks, currencies). Moscow: Magistr, 2014. 456 p.; Mirkin Y. M. Russia’s financial future: extremes, booms, system risks. Moscow: Geleos, Capital Trade Company, 2011. 496 p.; Mirkin Y.M. Stock market. Moscow: Finance Academy under the Government of the Russian Federation, 2002. 87 p.

As the table above clearly demonstrates, matters regarding asset pricing in general and stock pricing in particular within the stock market are still largely unclear. Some theories, commonly accepted by the professional and scholarly communities, contradict each 
other to a certain extent -for example, the efficient market concept and behavioral economics. This does not really indicate the error of one researcher or the other, but rather the complexity of the subject and economic science overall. Various concepts tend to work to a different degree, in various situations, for different assets and on different time frames. For instance, information is taken into account for asset pricing within the stock market, and the stock market can actually be considered rather efficient (especially as compared to other markets, which is largely connected to the universal nature of assets traded within it), but the degree of that efficiency varies largely depending on the time period. Pricing within the millisecond time frame tends to be far less efficient than pricing throughout decades, and can even be prone to manipulation, while no economic entity can possibly have enough resources to manipulate stock prices in the long run.

Pricing within the global stock market has not been researched nearly as thoroughly as other topics discussed above. Most works deal largely with particular aspects, while basic concepts have not been yet sufficiently developed. Such studies include the works of Russian scholars Sergey Aityan and Alexey Ivanov-Schitz [Ivanov-Schitz, Aityan, 2009]. Like other researchers dealing with that field, they did not examine basic concepts, instead focusing on specific properties. They used linear correlation analysis to study pair correlations between various regional stock markets represented by their respective indices. They demonstrated a link between stock indices (and stock markets) of various countries, even though the connections between different markets tends to change over time. This did not result in the overall model of interconnection of various countries' stock markets as affected by globalization, but showed the existence of such interconnection and its complicated nature.

Aspects of global stock market pricing most studied deal with practical, day-to-day matters of stock market specialists -for instance, price prediction, decision making, risk analysis, and so forth. Such works include research by Sarat Nayak, who discusses the complexity of financial time series prediction within the global stock market. The approach he offers is based on the extensive use of modern technologies, involves adaptive neuro-evolutionary models, and is designed for short, medium, and long-term forecasting [Nayak, 2017].

The major downside to many, if not most, work on practical matters of the global stock market is the ambiguity of the value they offer. This is connected mostly to the above-stated lack of general concepts, as well as to reliance on unproven, insufficiently researched and often unclear methods and concepts. A prominent example of the latter is technical analysis and numerous books dealing with it - a widely known and extensively used set of methodologies for explaining and predicting price movements, which, despite its popularity and considerable age (its concept was developed at least almost a century ago), does not have a clear definition, a defined toolset, or any proven record, and is clearly subjective, dependent on the particular user's view and perception.

Decades of use of the many tools and paradigms similar to technical analysis has brought forth arguments due to interpretation issues, when one and the same tool with the same parameters offered opposite results and solutions depending on the researcher. This flaw is often inherent: for instance, some authors interpret the crossing of two moving averages - a famous technical analysis indicator - as a sign of a trend beginning, while their opponents believe such crossing indicates its end. Both groups have fundamental arguments supporting their interpretations. Historical results of using trading strategies 
based on both of the opposite interpretations vary greatly depending on the assets, historical periods, and time frames used for testing. Overall, they can only be described as "volatile" and "unclear." Meanwhile, the essence of moving averages lies in the average past values, and due to the chaotic nature of the stock market, there is no fundamental evidence whatsoever in favor of the theory that they can be used for any practical purposes as far as future values and prediction thereof go [Moving Averages..., 2018].

Such flawed (at least from the theoretical point of view) mechanisms and ideas are surprisingly common within the global stock market. Using modern methodologies and technologies often does not fix matters, but, on the contrary, makes them worse. Errors within complex models containing a multitude of factors are much more difficult to trace. In some cases, like with neural networks, resulting algorithms might be impossible to define at all, and researchers might only have control of the algorithms of the network itself.

The models themselves might show good results for long periods of time during testing on historical data. Yet, they should still be considered not quite reliable unless they correspond with or, better yet, are founded upon fundamental properties of the global stock market and its prices. Thus, such properties must first be defined - based, in turn, on fundamental economic laws and proven by historical evidence and data.

\section{Theoretical concepts and empirical facts relevant to the research}

Formulating a clear and unified approach to pricing within the global stock market requires tying together a number of phenomena and fundamental economic concepts. The groundwork of this research has been laid in the previous paragraphs. This section discusses essential phenomena and their qualities most substantive within its context and ties together all the previously discussed matters in order to formulate that single approach. A major value of that approach lies in it relying on fundamental economic concepts and qualities of assets. This leads to it remaining essential and true despite rapid changes in the modern stock market, as long as those economic concepts remain the same and asset qualities (like stocks being able to generate dividends for their owners) do not change, the probability of which happening anywhere in the foreseeable future seems unlikely.

The first concept, and in some sense a major one, that needs to be discussed is the concept of economic growth. Many definitions rely heavily on specific indicators measuring economic growth, namely gross domestic product (GDP) [Sutyrin, Kovalenko, 2016]. A more distinct example of this approach is from the World Bank and the Commission on Growth and Development, which define economic growth as "growth of ... GDP" straight away [The Growth Report..., 2008]. Other sources define economic growth through gross national product (GNP); they sometimes further expand the definition by incorporating causes of economic growth, as well as other similar data. Paul Romer uses GDP per capita to define economic growth for his purposes; in his model, he examines growth as a result of endogenous processes [Romer, 2015]. Similar ideas are used by N. Gregory Mankiw in his research on the growth of nations, where he identifies growth through average income and connects it directly to the prosperity of nations [Mankiw, Phelps, Romer, 1995].

Such an approach on a wide scale can in fact be considered somewhat loose, for economic growth is in essence wider than any of its specific indicators [Yaluner, 2017]. It can be measured via various indicators, the most common of which, but not the only ones possible, are GDP and GNP. These same indicators per capita can also be used, though the 
exact choice depends on specifics and goals of measurement. For instance, a country with a high GDP will probably be capable of large-scale projects, like space programs, and will be an important player in the regional and possibly global markets, even though its GDP per capita may be comparatively low. Meanwhile, low GDP per capita may indicate different structural problems in the economy, such as low living standards, low productivity, as well as possible deceleration of economic growth rates in the future, but it tells nothing of the country's overall economic capabilities or significance within the more global context in and of itself.

Thus, economic growth universally cannot be precisely defined through any one of its indicators. A universal definition would involve a number of indicators, as well as qualitative assessments; narrower definitions can be used with more specific purposes in mind. A justified approach would be to offer a general definition, wide enough to include all types and all possible indicators of economic growth.

The two major types of economic growth are intensive and extensive growth. Extensive economic growth is due to the increase in resources used for production. Thus, it can be considered a quantitative indicator. Intensive growth is due to the increase of productivity caused by various reasons. Thus, it is a qualitative economic indicator [Abramovitz, David, 2001].

Extensive growth, as the above statement suggests, is dependent on factors of production. Classic economic factors of production are labor, land, capital, and entrepreneurship. The latter is somewhat unclear in terms of definition and measurement, although it can arguably be measured by indicators such as the number of enterprises or entrepreneurs in the economy. Overall, the increase of the amount of factors of production is responsible for extensive growth. In the world economy, the population is growing in the long run, and so does the amount of labor and entrepreneurship (even though in the regional or local contexts or in the shorter run it can decrease). The amount of land involved in production - agricultural and otherwise - also grows historically, even though this resource is limited and the rate of this growth is slowing down. The amount of capital is growing alongside the population, entrepreneurship, and technological progress. Thus, extensive economic growth is insured on the global scale in the long run. In shorter time frames or on a more local scale, the extensive component of economic growth will fluctuate.

As for intensive economic growth, productivity growth it is reliant on is mostly due to technological progress. Technological progress is happening to a certain extent irregularly, but unequivocally on a global scale in the long run. In the short or even medium run, technological progress can temporarily reverse, as well as on the regional or local scale. Thus, intensive economic growth is insured on the global scale in the long run. On the shorter time frames or more local scale, the intensive component of economic growth will fluctuate.

As will be demonstrated, pricing for most assets in the stock market can be closely related to economic growth through specific economic mechanisms. This also depends on a number of other factors, fundamental and temporary. The smaller the time frame, the larger the role of temporary factors, which are often dependent on market inefficiencies not yet eliminated. The larger the time frame, the more important the fundamental factors usually are. One major factor is the inherent properties of various assets, such as stocks. Other significant asset types available in the stock market are bonds, derivatives, commodities, and funds dealing with various assets traded within stock exchanges and 
otherwise. (For example, REITs or real estate investment trusts invest in commercial and residential real estate and serve as a link between stock market investors and the real estate market, even though real estate cannot be traded in it directly due to its nature.)

A corporate stock or share is "a type of ownership equity in a company or corporation for an investor. Each share owned by an investor represents a proportionate share of interest in that company" [Corporate stock..., 2018] There are different types of stocks, but the general idea is that they entitle the owner to the ownership of the part of the company proportionate to the volume of stocks they own. That ownership, however, is rather ephemeral. For the vast majority of stock investors, it is more theoretical than practical, due to the division of ownership and management functions. In practice, minority holders do not hold any say in matters of the company they "co-own" and have no influence on its policies by themselves whatsoever. Yet, despite all this, company stocks are not mere pieces of paper (or numbers on the screen in the modern day). They have fundamental value, which derives from their inherent properties. These properties are as follows.

1. Although corporate stocks are mostly useless for minority shareholders as far as company management is concerned, they can be extremely useful for majority shareholders or a group of significant shareholders holding the same views. That usefulness and the underlying profits it implies creates value for these stocks, which such shareholders would be willing to pay.

2. Stocks by their very nature possess a fundamental property for bringing dividends for their owners. This is especially true for stocks in general, as an asset class, since individual stocks might not return dividends depending on the management policies. Thus, fundamental value for stocks is created from their quality to generate income in the form of dividends.

Even though the current dividend yields for almost half S \& P500 companies, for instance, are below $2 \%$, and less than 40 of them yield over $4 \%$ in dividends, they remain an important pricing factor, for dividends directly link ephemeral stocks with the real world through money for most investors [The S \& P 500..., 2014]. Contemporary low dividend yields in general can be considered a factor decreasing the stability of the stock market in the medium run or on the local scale. It can be noted, however, that dividend yields are historically subject to change based on the total of the current investor views on the importance of dividends and companies' demand for funding via the stock market, as well as bond yields.

3. Stock prices for a successful company naturally grow in the long run - a tendency which has a strong proof in historical data. As far as unsuccessful companies go, once again, stocks in general, as an asset class, always grow within large time frames. For instance, MSCI World index, comprised of over 1500 companies across the world, rose from 100 points in 1969, when it was incepted, to 2101.07 on February 7, 2018, with the highest historical value of 2230.05 on January 23 of the same year [MSCI World Index..., 2018]. This amounts to total historical growth of $2230.05 \%$ over 49 years (at the highest point) or an average annual growth rate of about $6.5 \%$, as is shown in Figure 1.

The Dow Jones Industrial Average (DJIA) provides a look at a longer perspective, although at a more local scale. However, it is important to remember that during a significant part of its existence, the country it was created for, the United States, has been 


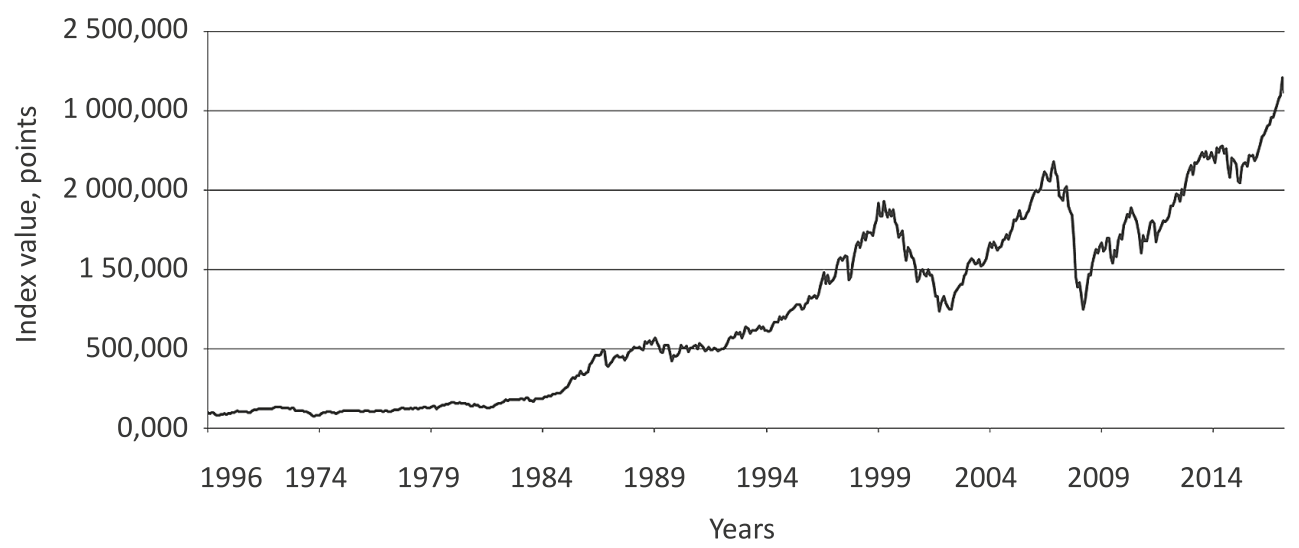

Fig. 1. MSCI World chart since 1969 until 2018

Source: MSCI World Index // MSCI. 2018. Available at: https://www.msci.com/world (accessed: 06.03.2018).

a dominant power in the global economy. DJIA value was first calculated in 1896, at which point it amounted to 29.39 points. Since that time, it rose to a recent historical high of 26,616.71 in January 2018. Its value on February 9, 2018 amounted to 23860.46, a total rise of $9563.8 \%$ over 122 years or average annual growth of $5.7 \%$, (Figure 2 ).

The quality discussed herein is somewhat connected to the quality to bring in dividends, as the decision not to pay dividends is normally justified by higher expected rates of price growth in case money is invested in the company instead. Thus, fundamental value for stocks is created from the quality of their prices to increase over large periods of time.

4. In the short and medium terms, stock prices fluctuate as per current market conditions, as historical evidence demonstrates. This quality is valuable only to speculators who try to profit from it; for investors, it is more of an obstacle, at least at first glance. Yet this can increase the demand for stocks, bringing speculators as a group into the equation and generating fundamentally justified value for them [Cagan, 2016].

The examples of this property are for all practical reasons limitless, especially since the widescale introduction of computer trading and intraday trading. Such trading can take place in time frames measured in less than several decades - from years down to milliseconds. As far as year a time frame goes, a great instance is provided by the abovementioned MSCI World index, with the longest period during which its value could not exceed its previous historical high of roughly six years (1973-1979, Figure 3).

This stock market crisis took place despite the estimated global GDP having grown from 4.591 trillion to 9.926 trillion current USD throughout that period (Fig. 4). It can be noted, however, that during such a comparatively short period, even though the end result was quite different, the correlation between MSCI World and global GDP dynamics amounted to 0.776 based on annual data provided by the above sources [MSCI World Index..., 2018; World GDP..., 2018].

The longest period during which the DJIA value could not exceed its previous historical high lasted roughly 25 years (1929-1954) [Dow Jones Industrial..., 2018]. Even though the beginning of this crisis was attributed to the Great Depression, throughout the whole period GDP for both the United States and the world rose significantly, and 


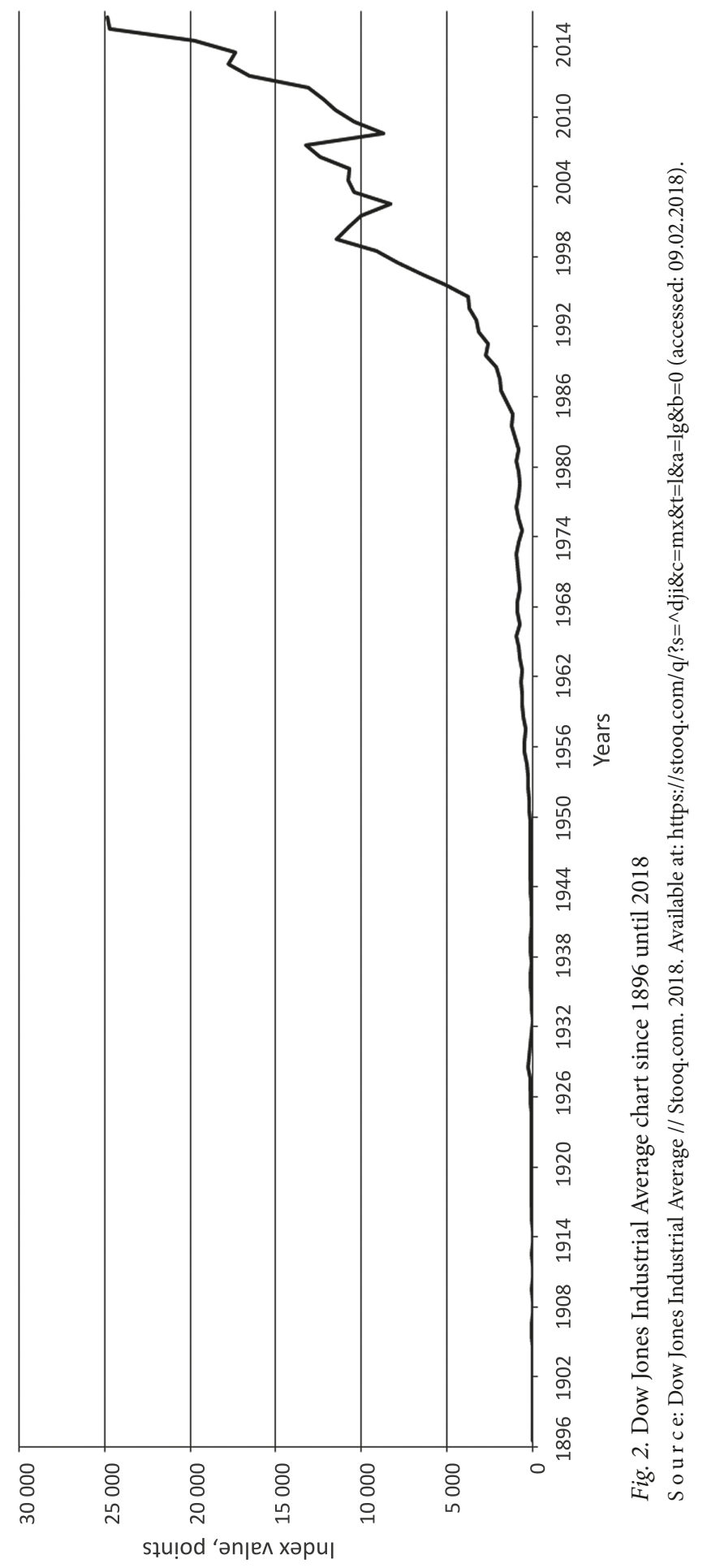




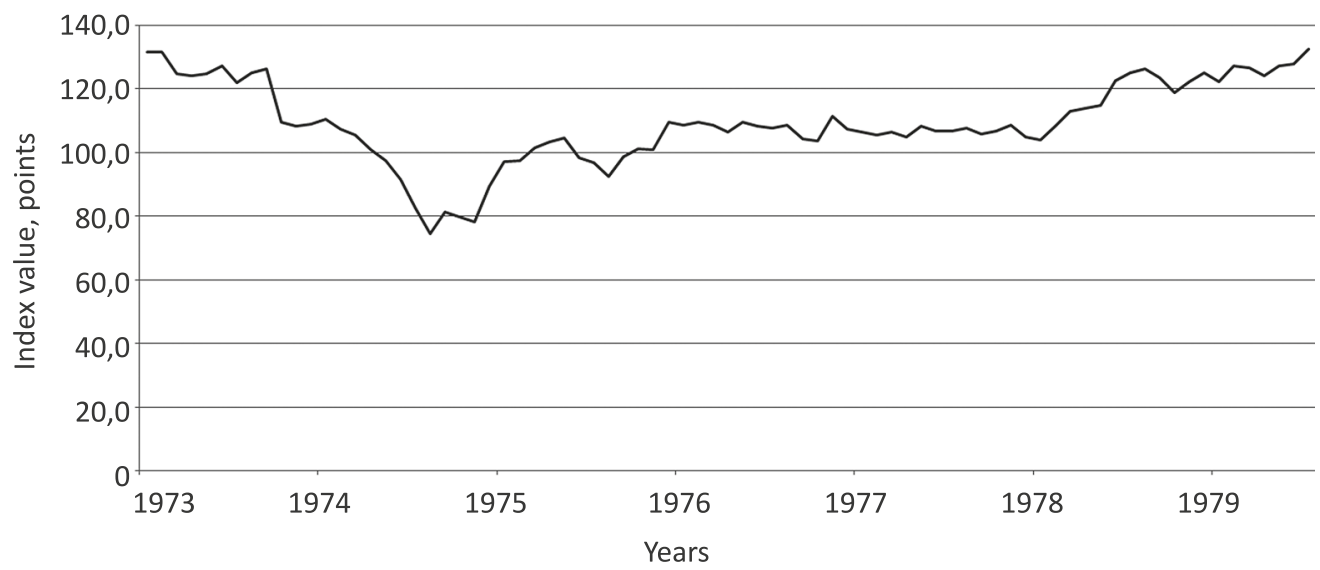

Fig. 3. MSCI World chart since 1973 until 1979

S o u r c e: MSCI World Index // MSCI. 2018. Available at: https://www.msci.com/world (accessed: 06.03.2018).

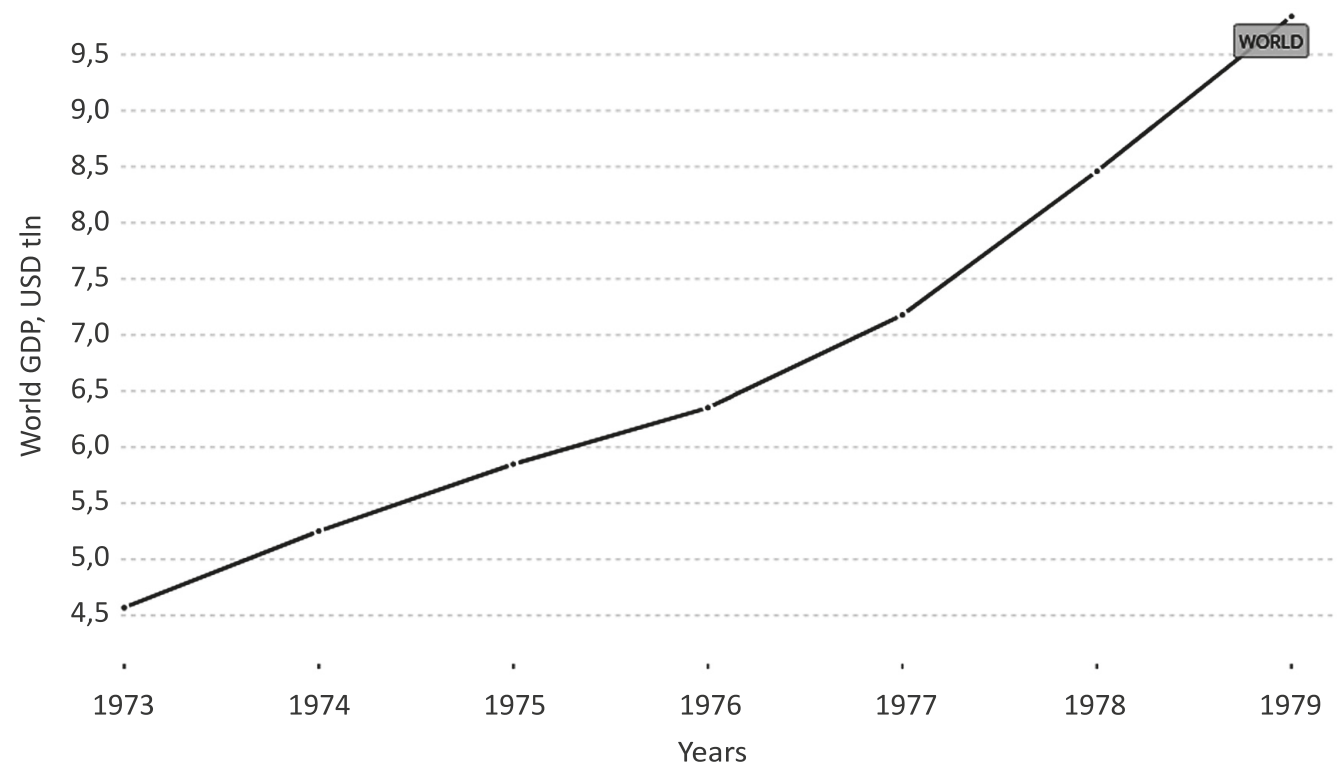

Fig. 4. World GDP since 1973 until 1979, trillions of current US Dollars

Source: World GDP (current US\$) // The World Bank. 2018. Available at: https://data.worldbank.org/ indicator/NY.GDP.MKTP.CD (accessed: 10.02.2018).

thus recuperation of the stock market came much later than recuperation of the economy [Maddison, 2007].

As for shorter time frames, the recent situation (end of January - beginning of February, 2018) can also serve as an example. MSCI World has fallen from its peak value of 2248.93 on January 26 to 2101.07 on February 7, a fall of about $6.6 \%$ [MSCI World Index..., 2018]. As is often the case in such situations, it did not fall due to a corresponding decline in the global economy of over $6 \%$ over a few days, or any decline at all. Just 
like most other short- or medium-term fluctuations, it was a result of the current market environment and possibly (though not necessarily) current opinions of market participants. And the shorter the time frame, the less influence the current economic situation has. The vast majority of intraday price changes is due to market factors and not economic factors, be they the economic growth rate or anything else: numerous deals are made every single second within the global stock market, and in the present age, a significant amount of those is made by algorithms, for which the fundamental economic situation is usually not a factor [Did Robot Algorithms..., 2018]. The present article does not aim to quantify the interdependence of economic growth and stock pricing, only to define its major tendencies. It is worth noting, however, that such quantification and study can provide important work for shedding light on a number of specific matters within the global stock market.

These properties are inherent to stocks, for they lie in their very nature. As long as stocks exist in their current form, they will conform to these properties. Thus, they will always have certain fundamental value and economic meaning.

Finally, the concept this research needs to address in order to succeed is the geographical aspect in relation to the stock market as well as economic growth. The main differences for global, regional, and local economic growth - both intensive and extensive - have been discussed above. For stock market, the same major differences apply. On the local and regional levels, countries and even regions have been known to go into decline, never to recover, at least as their old selves. When this happens, it is a major shock for the economies of the respective regions and countries, as well as for companies operating in them. This is especially true in the modern era of globalization, even though the world has not seen major regions with market economies fall in the recent decades. When a country or a region goes into decline, companies there, now operating on the global scale, are at a disadvantage vis-à-vis foreign competitors and can often sink as well. Thus, stock market growth is not guaranteed on the regional or country levels; moreover, a local stock market is sure to go down long-term in some manner at some point in history, for countries and regions have a natural tendency to disappear or significantly change due to the ever-shifting nature of human society.

For the global stock market this is not necessarily true. Historically, the global stock market and currently major local stock markets have been known to demonstrate steady growth over decades. Whether this tendency has sound, fundamental economic grounds and has been and will remain true is laid out below.

\section{Research results}

Tying all of the above-stated theories, facts, data, and definitions together allow the deduction of the following model. There are two types of economic growth: extensive (quantitative) and intensive (qualitative). The amount of inputs used in the global economy - labor, land, capital, entrepreneurship - is increasing over decades because not all resources available having yet been explored, due to a natural increase of the amount of some resources (e.g. labor, which derives from the ever-growing population) and due to technological progress allowing the use of resources that were inaccessible earlier. On the more local scale or in the shorter run, this amount fluctuates. The efficiency of input usage is growing for the global economy in the long run due to technological progress. On the 
more local scale or in the shorter run, this amount fluctuates: technological progress can stop or even reverse for a single country or for a few years.

These factors guarantee economic growth on the global scale in the long run (decades and more). Since factors for both extensive and intensive growth do not guarantee these types of growth for shorter time frames or locally, insuring fluctuation instead, indicators for overall economic growth, like GDP and others, also fluctuate under these conditions, and economic growth might or might not occur.

These conclusions are confirmed by historical evidence. Although different sources offer different valuations of economic growth, especially in the long term (across centuries), they all agree that economic growth has been happening within those larger time frames at an increasing pace [Maddison, 2007]. That increasing pace of growth confirms economic growth to be a derivative of technological development as a factor of intensive growth and the increase of input usage as a factor of extensive growth. The somewhat clear and definite data available from the World Bank for the period 1960-2016 demonstrates growth from 1.367 trillion. current US Dollars in 1960 to 75.845 trillion in 2016 [World GDP..., 2018]. That constitutes total economic growth of $5548 \%$, or the average annual growth of $9.12 \%$.

When the economy is growing, companies operating in it are also growing, and so does their valuation. Since in theory corporate stocks represent ownership of the corporation that issued them, their price should also increase along with economic growth. This is confirmed by historical evidence: for instance, from 1969 to 2016, global GDP, as per sources noted above, has risen by $2818 \%$, an average annual growth of $7.36 \%$ [World GDP..., 2018]. Over the same period MSCI World index has risen by $1752.96 \%$ - the average annual growth of $6.28 \%$ [MSCI World Index..., 2018]. The correlation during that period between MSCI World and global GDP dynamics amounts to 0.927 [MSCI World Index..., 2018; World GDP..., 2018]. It is worth noting that stock prices historically grow at a faster pace over very long periods of time than GDP, which in fundamental terms derives from both private and public companies being run more efficiently than companies, non-profit organizations, state entities, and other GDP constituents combined [MSCI World Index..., 2018; Dow Jones Industrial..., 2018; Maddison, 2007].

All in all, in practice stock prices are formed by supply and demand. The mechanisms that in practice influence supply and demand for stocks rely on their inherent economic properties described above.

Stocks actually provide the opportunity to influence company management for larger investors, who are willing to pay more money for that ability as companies grow. For smaller investors, stocks bring in dividends; as corporate profits increase, so do dividends. Prices not reacting to dividend increases long enough create attractive price-to-dividend ratios, prompting investors to use this temporary inefficiency and driving up demand (and prices).

To a certain extent, stock prices are a result of the majority's belief in stocks representing actual companies, since in reality only a small minority of stock owners can actually influence anything inside them. This belief, however, is not an economic mechanism and, moreover, can decrease or increase in any time frame. It introduces a chaotic component prone to fluctuations of overall long-term stock price trends. Yet, the two factors described above ensure stock prices will have an upwards trend in the long run on the global scale.

One is the connection between economic growth and corporate stock pricing. In the shorter run or on the local scale, economic growth might not happen. Moreover, the 


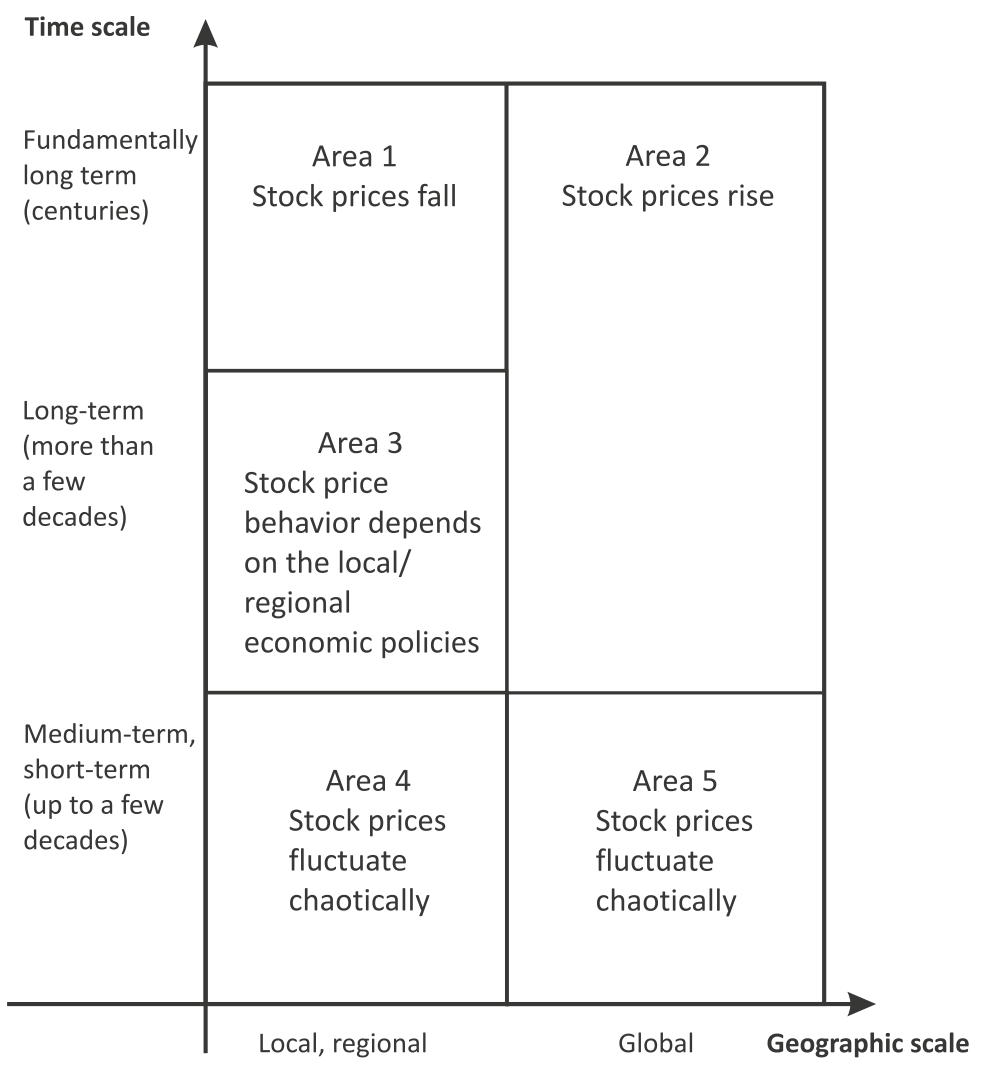

Fig. 5. Fundamental stock price tendencies resulting from economic factors and market infrastructure as measured by dynamics of respective stock indexes

smaller the scale, in terms of time or geography, the more stock prices can be influenced by the current market environment. This fact is clearly demonstrated by so-called "flashcrashes," when actions or market manipulations of a relatively small number of people drive prices down significantly without any economic justifications, if only for a little while. Likewise, on the smallest time frames, like milliseconds, market inefficiencies make the day as far as decision-making for buyers and sellers goes, while fundamental factors are only taken into account in the context of these inefficiencies. Inefficiencies on a wide scale, however, are always economic in nature, and thus fundamentally justified. Across decades and on a global scale, they are almost completely eliminated by the market, and no entity can possibly accumulate enough resources to manipulate prices within these terms.

Stock pricing tendencies resulting from economic growth and other factors described above can be summed up in the following manner (Fig. 5).

In Fig. 5, stock prices tend to fall within Area 1 (the fundamentally long run for regional or local stock markets). This conclusion seems quite controversial, yet it stands true from the fundamental economic point of view, for even the strongest and most stable countries and empires crash or dissipate over time, and so do companies therein. Even if in the future another country or regional group arises on the same territory, it will have 
another stock market with mostly different companies, as proven by history [Ancients in the Modern..., 2006; Keeping It ..., 2014].

Area 2 is where stock price growth is fundamentally guaranteed as long as humanity exists, at least in its current form and with market institutions. This is due to the strong connection of economic growth and stock pricing, as described above, combined with inherent properties of stocks as an asset class. For several decades and centuries, major properties of economic growth and stock pricing on the global level are the same, so they can be united into one group.

Area 3 holds an element of uncertainty: a country can be successful in the relatively long run, but this is not guaranteed. A stock market over decades is mostly dependent on its underlying economy, and the period is too long for the current market environment and market inefficiencies to play a leading role in stock pricing. And the underlying economy can either succeed or fail, depending mostly on economic policies. This area is the only one where the pricing tendencies are uncertain. Historically, the possibility of a local stock market downfall lasting that long can be confirmed by several occasions, most notably, the events in the Japanese market, which has not yet recuperated after its price bubble burst in 1989, when the leading index Nikkei 225 fell from its 38957.00 historical maximum to the current corridor between 7021.28 and the recent highest value for well over two decades of 24129.34 [Nikkei 225..., 2018].

In Areas 4 and 5, stock prices fundamentally fluctuate. Their growth is not insured by economic growth, since on that scale economy declines as well as grows, or by any other economic factors. Moreover, no factors can contribute to stock prices' fundamental decline in those areas. Here, they are mostly dependent on current market environment either alone or in combination with economic growth and decline stages of economic cycles, and thus fluctuate chaotically.

\section{Conclusion}

The facts above clearly show a strong fundamental connection between economic growth and stock pricing. Economic growth has an especially extensive influence on overall stock prices for the long term in the global stock market that can be measured, for instance, by global stock indexes such as MSCI World, BBC Global 30, S \& P Global 1200 and others. Although pricing tendencies differ across asset types, depending on their fundamental economic qualities, our model can be applied across all these as well, even if they are not traded within the global stock market directly, as long as mechanisms under which they are traded are similar to those of the stock market. Thus, possibilities for further research include defining fundamental economic qualities inherent to other asset types besides stocks, and from there identifying their pricing tendencies with regard to time frames and geographic scale. These theoretical tendencies should then be compared to actual historical data for respective assets, so that final conclusions could be made.

Another challenging subject for research is analyzing fundamentally long-term economic cycles in the global economy, measured by millennia, and identifying the nature of pricing for various assets. It is clear that economic growth happens across that large a time frame, but the big question remaining is: what exactly does it look like? It is unclear whether it is cyclical throughout the human history, as is the case for smaller time frames, or whether it is uneven, with periods of growth chaotically changing into undefined 
periods of depression, and whether the outlook for fundamentally long economic growth changes with time and technological progress.

It is also worth noting that while the methodology developed here is suitable for identifying pricing tendencies for stocks and other asset types traded within global, regional, and local stock markets, it cannot be used, at least as is, for all major tendencies for many asset types bought and sold outside them. This limitation is due to the specific qualities of assets traded within the stock market, such as uniformity, interchangeability, divisibility, and so on.

As for stocks, the tendencies described above are confirmed both by historical data and existing theoretical work on technical properties of stock price movement. The model presented here provides a fundamental explanation as to why prices move as they do and insures that these are indeed tendencies that will persist into the future, since they have theoretical and practical economic foundations, as opposite to random phenomena that can cease to exist at any moment.

\section{References}

Abramovitz, M., David, P.A. Two Centuries of American Macroeconomic Growth. From Exploitation of Resource Abundance to Knowledge-Driven Development. Stanford Institute for Economic Policy Research, 2001. 216 p. Available at: https://siepr.stanford.edu/sites/default/files/publications/01-05_0.pdf (accessed: 20.01.2018).

Ancients in the Modern World. The Daily Telegraph, 2006. Available at: https://www.dailytelegraph.com.au/travel/ ancients-in-the-modern-world/news-story/a665b86abd37555ef16f5f791d415466 (accessed: 02.02.2018).

Bansal R., Yaron A. Risks for the long run: a potential resolution of asset pricing puzzles. The Journal of Finance. 2004, vol.59, no. 4. pp. 1481-1509.

Cagan M. Stock Market 101: From Bull and Bear Markets to Dividends, Shares, and Margins - Your Essential Guide to the Stock Market. Avon, MA: Adams Media, 2016. 282 p.

Corporate stock. Business Dictionary. 2018. Available at: http://www.businessdictionary.com/definition/corporate-stock.html (accessed: 11.01.2018).

Did Robot Algorithms Trigger Market Plunge? BBC News. 2018. Available at: http://www.bbc.com/news/business-42959755 (accessed: 11.02.2018).

Dow Jones Industrial Average. Stooq.com. 2018. Available at: $\mathrm{https} / / / \mathrm{stooq} \cdot \mathrm{com} / \mathrm{q} / \mathrm{s}=\wedge \mathrm{dji} \& \mathrm{c}=\mathrm{mx} \& \mathrm{t}=\mathrm{l} \& \mathrm{a}=\lg \& \mathrm{~b}=0$ (accessed: 09.02.2018).

Fama E. Random walks in stock market prices. Financial analysts journal, 1965, vol.21, no. 5, pp. 55-59.

Graham B., Zweig J. The intelligent investor: the definitive book on value investing. New York, Collins business, 2003. $640 \mathrm{p}$.

Ivanov-Schitz, A.K., Aityan, S.H. Russia's integration into the global economy and financial markets' globalization [Integratsiia Rossii v mirovuiu ekonomiku i globalizatsiia fondovykh rynkov]. Vestnik MGIMOuniversiteta [MGIMO-University Bulletin], 2009, no. 6, pp. 56-65. (In Russian)

Kahneman D., Tversky A. Advances in prospect theory: cumulative representation of uncertainty. Journal of Risk and Uncertainty, 1992, no. 5, pp. 297-323.

Kahneman D., Tversky A. Prospect theory: An analysis of decision under risk. Econometrica, 1979, vol. 47, no. 2, pp. 263-292.

Keeping It in the Family. Why are so many of the world's oldest companies in Japan? Slate. 2014. Available at: http://www.slate.com/articles/business/continuously_operating/2014/10/world_s_oldest_companies_ why_are_so_many_of_them_in_japan.html (accessed: 02.02.2018).

Maddison A. Contours of the World Economy 1-2030 AD: Essays in Macro-Economic History. Oxford, Oxford University Press, 2007. 432 p.

Mankiw N. G., Phelps E. S., Romer P. M. The Growth of Nations. Brookings Papers on Economic Activity, 1995, vol. 1995, no. 1, pp. 275-326.

Mirkin Y.M. Finansovoe budushchee Rossii: ekstremumy, bumy, sistemnye riski [Russia's financial future: extremes, booms, system risks]. Moscow, Gelios, Kepital Treid Kompani, 2011. 496 p. (in Russian)

Mirkin Y. M. Mezhdunarodnaia praktika prognozirovaniia tsen na finansovykh rynkakh (syr'e, aktsii, kurs valiut) [International practice of financial markets' price forecasting (commodities, stocks, currencies)]. Moscow, Magistr, 2014. 456 p. (In Russian) 
Mirkin Y. M. Rynok tsennykh bumag [Stock market]. Moscow, Finansovaia akademiia pri Pravitel'stve RF, 2002. 87 p. (in Russian)

Moving Averages - Simple and Exponential. StockCharts. 2018. Available at: http://stockcharts.com/school/ doku.php?id=chart_school:technical_indicators:moving_averages (accessed: 15.01.2018).

MSCI World Index. MSCI. 2018. Available at: https://www.msci.com/world (accessed: 06.03.2018).

Nayak S. Global Stock Market Prediction and Analysis. Saarbrucken: LAP Lambert Academic Publishing, 2017. $160 \mathrm{p}$.

Nikkei 225. Stooq.com. 2018. Available at: https://stooq.com/q/d/?s=\%5Enkx\&c=0\&d1=19850301\&d2=201802 09\&i=y (accessed: 11.02.2018).

Romer P. Economic Growth. Paul Romer. 2015. Available at: https://paulromer.net/economic-growth/ (accessed: 10.04.2018).

Shavshukov V.M. Krizisy global'nykh finansov: priroda i zakonomernosti [Global financial crises: essence and regularities]. Mir peremen [Changing world], 2015, no. 1, pp. 134-148. (In Russian)

Shiller R. Do stock prices move too much to be justified by subsequent changes in dividends? The American economic review, 1981, vol.71, no. 3, pp. 421-436.

Sutyrin S. F., Kovalenko V. N. Internatsionalizatsiia valiut v Vostochnoi Azii: predposylki, realizatsiia proekta, vozmozhnye perspektivy [Currency internationalization in Eastern Asia: prerequisites, project realization, possible perspectives]. Vestnik of Saint-Petersburg University. Economics, 2016, no. 1, pp. 20-41. (In Russian)

The Growth Report. Strategies for Sustained Growth and Inclusive Development. The World Bank on behalf of the Commission on Growth and Development. The International Bank for Reconstruction and Development 2008. Available at: http://siteresources.worldbank.org/EXTPREMNET/Resources/489960-1338997241035/Growth_Commission_Final_Report.pdf (accessed: 08.01.2018).

The S\&P 500: A Dividend Yield \& Growth Overview. Dividend.com. 2014. Available at: http://www.dividend. com/how-to-invest/the-sp-500-a-dividend-overview/ (accessed: 05.02.2018).

Wessel D. Did 'Great recession' live up to its name? The Wall Street Journal. 2010. Available at: http://online.wsj. com/article/SB10001424052702303591204575169693166352882.html (accessed: 18.01.2018).

World GDP (current US\$). The World Bank. 2018. Available at: https://data.worldbank.org/indicator/NY.GDP. MKTP.CD (accessed: 10.02.2018).

Yaluner E. V. Tendentsii razvitiia predprinimatel'stva [Entrepreneurship development trends]. Strategii razvitiia predprinimatel'stva $v$ sovremennykh usloviiakh: sb. nauch. tr. I mezhdunarodnoi nauchno-prakticheskoi konferentsii [Collected works: Entrepreneurship development strategies in the contemporary environment. Collected scientific works of the $\mathrm{I}^{\text {st }}$ international applied research conference]. Eds E. A. Gorbashko, V.G.Shubaeva. 2017, pp. 12-14. (In Russian)

Received: February 26, 2018

Accepted: June 25, 2018

Author's information:

Michael M. Loubochkin — PhD in Economics; michaelmml@mail.ru

\section{Экономический рост и ценообразование на акции предприятий на мировом фондовом рынке}

\section{М. М. Лубочкин}

Санкт-Петербургский государственный экономический университет, Российская Федерация, 191023, Санкт-Петербург, ул. Садовая, 21

Для цитирования: Loubochkin M. M. Economic growth and company stock pricing in the global stock market // Вестник Санкт-Петербургского университета. Экономика. 2018. Т. 34. Вып. 3. C. 396-414. https://doi.org/10.21638/spbu05.2018.303

В настоящей работе рассматривается фундаментальный подход к изучению ценообразования на акции и другие активы на мировом фондовом рынке. Вопросы цено- 
образования на мировом фондовом рынке на различные торгуемые активы в целом и на акции компаний в частности к настоящему моменту исследованы и изучены недостаточно. Хотя отдельные вопросы, например корреляция и взаимосвязь между разными национальными фондовыми рынками, представленными соответствующими индексами, были достаточно полно отражены в научной литературе, основы по данной проблематике и множество других проблем в значительной мере остались без внимания исследователей. Это такие вопросы, как природа и причины движения цен на фондовом рынке для долго-, средне- и краткосрочного периодов, фундаментальные различия в движении цен на разные виды активов, разница в ценообразовании для глобального, региональных и местных фондовых рынков. Указанные проблемы в значительной степени связаны друг с другом, а также с естественными свойствами различных активов, фундаментальными экономическими законами и, в определенной степени, с экономическим ростом. Для того чтобы успешно их исследовать, все эти вопросы необходимо увязать в рамках единого подхода, который позволит сформулировать основные принципы ценообразования на акции на мировом фондовом рынке. Впоследствии их можно будет расширить и перенести на другие типы активов. Это позволит сформировать основы для проведения в дальнейшем более глубоких исследований, а также для выявления и исправления ряда ошибок и неточностей в существующих работах. В настоящей статье поставлена цель решить данную задачу и таким образом способствовать созданию более четкого и унифицированного подхода к изучению ценообразования на акции в контексте экономического роста и за его пределами, который могли бы применять как исследователи-теоретики, так и специалисты, работающие на фондовом рынке.

Ключевые слова: экономический рост, мировой фондовый рынок, ценообразование на акции, экономика предприятий, инвестиции, спекуляции.

Контактная информация :

Лубочкин Михаил Михайлович — канд. экон. наук; michaelmml@mail.ru 